\title{
Intersex surgery disregards children's human rights
} Infancy is too early to take an irreversible step that may assign a child to the wrong sex.

Sir — The Androgen Insensitivity Syndrome Support Group of Australia congratulates Nature on its detailed and thought-provoking article "The most important sexual organ" (Nature 427, 390-392; 2004). Clinical management of children affected by intersex conditions is very difficult and controversial, largely because of the many ethical and legal considerations. (See www.vicnet.net.au/ aissg for more information.)

Countries across the world, along with the United Nations, have long recognized the rights of children to physical integrity and have banned the practice of female genital mutilation. True, the operations performed on children with intersex conditions are set in a proper clinical environment and are intended to help them develop a gender identity. But the lasting effects of reducing potential for full enjoyment of sexual experiences are often ignored — along with a person's right to make informed decisions.

What about the $8 \%$ of children with intersex conditions who are raised in the wrong sex? Are these children's lives not worth the price of waiting to perform irreversible surgery?

The day will soon come when doctors will be sued for performing these nontherapeutic operations, and I will welcome that day. If common sense is not enough, it will take the risk of litigation to make some doctors rethink the treatment of children with intersex conditions.

Tony Briffa

AIS Support Group Australia, PO Box 1089,

Altona Meadows, Victoria 3028, Australia

\section{Dedication put Møller ahead, not fabrication}

Sir - As collaborators of Anders Pape Møller we were shocked and surprised to read that he could have been accused of data fabrication ("Prolific ecologist vows to fight Danish misconduct verdict"

Nature 427, 381; 2004).

We have never had cause to be concerned about any aspect of our collaborations. Møller is an admirable scientist, and his great organizational skills are a model of how to be productive in the face of competing time demands.

Most people are capable of much more than they actually accomplish, but they lack Møller's dedication and self-discipline. This is the secret of his phenomenal success, which has been so puzzling to the rest of the community. Clearly, these achievements have caused negative responses from some of his competitors. We would like to see a full, objective and independent inquiry into the allegations made against Møller.

Our experience tells us that Møller has the ability to completely focus on any task at hand, be it fieldwork, data analysis or writing papers. This, combined with more than a little natural talent, is sufficient to explain his exceptional productivity. We have worked with Møller on several projects, including collecting data under sometimes arduous conditions, and in all our dealings with him his behaviour has been beyond reproach.

We would ask colleagues to refrain from further public condemnation until any allegations have been proven beyond doubt.

Juan Moreno*, Tim Mousseau $\dagger$

*Departamento de Ecología Evolutiva, Museo

Nacional de Ciencias Naturales-CSIC,

J. Gutiérrez Abascal 2, E-28006 Madrid, Spain

$\dagger$ Department of Biological Sciences,
University of South Carolina, Columbia,

South Carolina 29208, USA

Signed on behalf of 31 other international co-authors,

whose names and contact details are available at

http://cricket.biol.sc.edu/dedication/authors.html.

\section{Getting in a twist again}

Sir - I must start by saying that I am somewhat anal retentive (in other words I am a scientist), although I prefer the personality descriptor 'analytical'. That said, I could not help but note that a chromosomal DNA duplex used to illustrate a recent News and Views article (Nature 427, 593; 2004) has a left-handed screw axis. I note the occurrence of these not-infrequent aberrations as a form of personal entertainment with perhaps a touch of masochism, as it annoys the hell out of me for some reason.

Anyway, this example was particularly noteworthy because of the Correspondence by Stanley Scher in the same issue (Nature 427, 584; 2004) in which he rebuts an earlier comment by John Maddox about the Watson and Crick duplex structure being self-evident. Apparently it is not. It seems that even after 50 years and countless renderings of the famous B-form DNA duplex, people still get it wrong about $15 \%$ of the time (my non-peerreviewed, unpublished and incomplete survey). I can only conclude that the structure and its correctness are anything but self-evident, at least as far as advertisers and scientific illustrators are concerned.

In fairness I must note that there is the outside chance that Figure 1 was depicting a rare and controversial chromosomal Z-DNA domain, but even so, the helical parameters are way off.

Eric "my DNA is (mostly) right-handed and double-stranded" Henderson

Genetics, Development and Cell Biology,

Iowa State University, Ames, Iowa 50011, USA

\section{US visa restrictions harm job prospects abroad too}

Sir - It was with great interest that I read your News Feature "As one door closes..." (Nature 427, 190-195; 2004), on restrictive visa requirements in the United States and the impact they are likely to have on science. As a postdoctoral researcher from Australia, working in Alabama, I recently discovered how US visa restrictions can affect career choices for people already working in the United States.

Last June, after working in the United States for about five years, I submitted an application to renew my H1B visa. In February this year, the Immigration and Naturalization Service (INS) finally began to look at my application. In the meantime I had applied for an academic position in my native Australia. To my delight I was granted an interview; this was a dream job for me. But after applying for a US visa, you cannot leave the United States without jeopardizing your application. So I was faced with a tough choice: to go to the interview and risk losing my current job, or to stay in the United States and miss the job opportunity. With employment prospects as limited as they are in the natural sciences, I decided to travel to the interview.

A few weeks ago I was told that the INS would not be considering my visa renewal, and I would have to leave the country. Fortunately for me the gamble paid off, as I got the job in Australia. Nonetheless, I will have to cut my research short in the United States and, had I not got the job, I would now be unemployed. In my view, the way that the INS can effectively stop you pursuing jobs for protracted periods will make the United States even less appealing to foreign postdocs and academics.

\section{Toby F. Bolton}

Dauphin Island Sea Lab, 101 Bienville Boulevard, Dauphin Island, Alabama 36528, USA 